\title{
Reducing the Risks of Crude Oil Tanks Operation by Means of Automating Bottom Water Drainage and Bottom Sediment Removal Processes
}

\author{
Marat Teregulov, Leonid Zemlerub, Anastasiya Mashkova, Emil Kharasov \\ Samara state technical university, Russia, Samara
}

doi: https://doi.org/10.21467/abstracts.93.104

\begin{abstract}
A BSTRA CT
Tank batteries (TB) for storage of crude oil and petroleum products are hazardous production facilities (HPF). Almost half of the accidents occurring in the oil and gas industry takes place in TB. The most effective way to reduce risks of HPF operation is to implement additional functions of automated control systems (ACS) of technological processes (TP). During the TB operation two hours after oil intake and deposition bottom water drainage (BWD) from vertical steel tanks (VST) is performed by manual opening of a ball valve on a siphon crane located in the lower ring of VST. The manual opening of the valve increases possibility of an oil release into a sewerage system and a risk of personnel injury.

Nowadays, there are more and more cases at TB when after the end of sediment erosion system (SES) operation raised bottom sediments are not pumped out of the VST. Thus, large amount of erosion-resistant bottom sediments accumulates which leads to a failure of tank equipment and an unplanned total overhaul. For this purpose, tank must be decommissioned, which includes: complete emptying, steaming, degassing and cleaning of walls and bottom from solid sediments. Tank cleaning is the most dangerous operation with the highest number of accidents. In response to the need to improve the safety of TB Economic Commission for Europe member countries have developed guidance on safety measures and common industry practices for TB as part of a project to improve hazard and crisis management [1].

Over the past decades, workplaces have undergone technological improvements. These changes have had a strong impact on the system of health, safety and environmental protection. In some cases, hazard and risk levels have been reduced or eliminated, for example, through industrial automation. At the same time, traditional risks remain in many workplaces and the number of occupational accidents and diseases is still unacceptably high [2].

In the article it is proposed to supplement the ACS TP of TB with two new systems: BWD system and the system of accumulation and removal of bottom sediments which will lead to an elimination of a "human factor" and a reduction in risks, tanks operation costs, environmental and waste water pollution and reduction of oil sludge formation and a volume of their disposal.

Automation of the drainage process is achieved by installing on a siphon crane a motor-operated ball valve and an indicator of oil concentration in water. The novelty of the proposed solution lies in the algorithm of iterative drainage process. When you reach a given concentration the alarm will notify you and send a signal to close the ball valve. Then with further bottom water settlement the drainage operation is repeated in an iterative cycle which reduces the weight of the ballast and increases the profitability of oil transport.

Currently, the removal of bottom sediments from the VST is carried out by SES. The principle of its operation is based on the energy of a rotating screw which swings in a horizontal plane, rotating the entire mass of oil in the tank. This ensures the formation of suspended particles of bottom sediments which are removed through the VST inlet-distribution nozzles significantly reducing quality indicators of a shipped batch after bottom sediments erosion process.
\end{abstract}

(C) 2020 Copyright held by the author(s). Published by AIJR Publisher in "Abstracts of The Second Eurasian RISK-2020 Conference and Symposium" April 12- 19, 2020, Tbilisi, Georgia. Jointly organized by AMIR Technical Services LLC, Georgian Technical University, Institute of Geography (Kazakhstan) and Russian Institute of Petroleum Geology and Geophysics.

DOI: $10.21467 /$ abstracts.93 
The Second Eurasian RISK-2020 Conference and Symposium

It is proposed to supplement the SES in the VST with a system for accumulation and removal of bottom sediments. For this purpose, it is suggested to equip tank bottom around the perimeter with sediment collecting pits for bottom sediments accumulation. The sump pits are connected to a heated drainage pipe equipped with a shut-off valve and a sludge pump. After accumulation of a certain amount of sediments in the sump pit the heating automatically turns on, shut-off valves open and the slurry pump activates.

Thus, the proposed system will not only ensure timely removal of bottom sediments from the VST but will also lead to a reduction in the volume of solid sediments which are removed before tank repair shutdown, hence reducing the risk of this operation. With exploiting this technology, it will be necessary to organize a production plant for processing of removed from VST oil sludge in order to return 7-15\% of oil and to send asphaltene part for bitumen and asphalt production which will lead to a rapid decline in oil sludge disposal volumes and will ensure the reduction of payments for negative environmental impact.

All objects of oil transportation and storage and especially technological operations at TB are characterized by high technogenic and ecological hazards. Thus, during the process of filling tanks and cisterns an explosive gas-air mixture is released into the environment. In case of natural temperature difference from night to day the same emission occurs but in a smaller volume. These processes are called large and small tank breathing.

To reduce losses of crude oil and petroleum products and to protect the environment pontoons and floating roofs are installed on the tanks which helps to reduce emissions by $87-92 \%$. Since recently bulk plants are equipped with automatic vapor recovery systems which will completely eliminate emissions and reduce the risk of fires in TB. Equipping TB with the system of continuous monitoring of gas-air environment using sensors installed inside the tank dyking and in the leak detection wells will ensure safe working conditions and will reduce the risk of fires.

In a risk assessment it is important to identify the hazard and its sources. Qualitative and quantitative risk identification is of great importance at the stages of development, construction and placing in commissioning of new facilities as well as in determining the terms of safe operation of existing facilities [3]. From the brief review of technological operations carried out in the TB and the hazards they represent it follows that the introduction of additional functions of the ACS TP will remove personnel from the risk zone and, thus, significantly increase the safety of TB operation.

\section{References}

1. UNITED NATIONS ECONOMIC COMMISSION FOR EUROPE Safety Guidelines and Good Industry Practices For Oil Terminals- 2015 - ECE/CP.TEIA/28;

2. Bulavka U.A. (2011). Analiz proizvodstvennogo travmatizma na neftepererabatyvayushchem predpriyatii [Industrial injury analysis at an oil refinery]. Vestnik polockogo gosudarstvennogo universiteta [Glossary of Polotsk State University], 2011(3), 130-137 (in Russian);

3. Varnakov D.V., Zheltov D.V., Yashin D.N. (2018). Ocenka riska na ob'ektah neftyanoj promyshlennosti [Risk assessment at petroleum facilities]. Nauchno-prakticheskij elektronnyj zhurnal "Alleya Nauki" [Scientific and practical electronic journal “Alley of Sciences”], 2018(10), 26 (in Russian). 